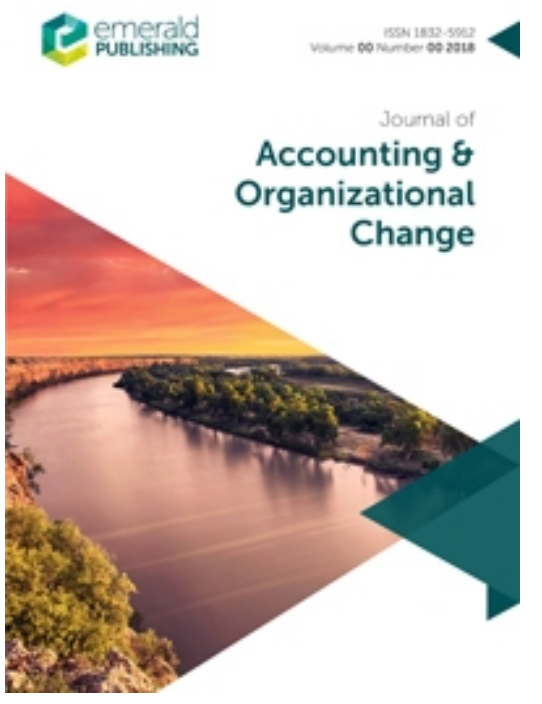

\title{
An empirical study of sustainability reporting assurance: current trends and new insights
}

\begin{tabular}{|r|l|}
\hline Journal: & Journal of Accounting \& Organizational Change \\
\hline Manuscript ID & JAOC-05-2020-0060.R3 \\
\hline Manuscript Type: & Research Paper \\
\hline Keywords: & $\begin{array}{l}\text { sustainability reporting, assurance, non-financial reports, assurance } \\
\text { switching }\end{array}$ \\
\hline \multicolumn{2}{|l}{} \\
\hline
\end{tabular}

\section{SCHOLARONE ${ }^{\text {m }}$ \\ Manuscripts}




\title{
An empirical study of sustainability reporting assurance: current trends and new
}

\section{insights}

\begin{abstract}
:
Purpose: This study aims to examine trends in the global assurance practices of sustainability reports, updating and broaden the extant literature and proving new insights that could guide future research.
\end{abstract}

Design/methodology/approach: The data were collected for 12,783 companies and exploratory descriptive analyses of sustainability reporting assurance practices were undertaken.

Findings: The study shows that assurance growth is lagging behind the growth in sustainability reporting. It reveals that assurer switching is a common practice among companies. There is an increasing trend towards the use of the ISAE 3000 by non-accounting assurers. Additionally, in terms of assurance providers, the study finds that accounting firms are dominating the market, however engineering firms are fast increasing their share of the sustainability assurance market, while consulting firms share is decreasing However, the switch towards consulting firms is higher than the switch towards accounting firms in the last switch period.

Originality/value: Prior studies on the assurance practices of sustainability reports are limited in scope (concentrate on large companies) and depth (examine accounting vs non-accounting assures and consider the evolving patterns at the institutional rather than firm-level). This study presents developments and trajectories of assurance practices to inform researchers and practitioners on the global trends by bringing an updated and broader perspective on the topic.

Practical implications: Overall, the results of this study provide insights about companies' assurance practices for regulators, assurance providers and companies interested in assuring their sustainability reports.

Social implications: This study is relevant for companies' stakeholders, including investors, to enhance their understanding of companies' current assurance practices.

KEYWORDS: sustainability reporting, assurance, non-financial reports, assurance switching 


\section{INTRODUCTION}

The issuance of sustainability reports has grown rapidly over the past two decades. Despite being currently a voluntary practice in most countries, $96 \%$ of the world's 250 largest global companies (G250) produce sustainability reports (KPMG, 2020). Lately, there has been a trend towards mandating such reports. In 2010, the Johannesburg Securities Exchange (JSE), following the King III report (IoDSA, 2009), required all listed companies to produce an integrated report (ACCA, 2015). In addition, the European Parliament in 2011 called on the European Commission to make a legislative proposal on disclosing non-financial information (European Parliament, 2012). The European Parliament agreed in 2014 to issue the EU Non-Financial Reporting Directive. The Directive required large European companies to provide sustainability reports, beginning in 2018 (European Parliament, 2014). Furthermore, the European Commission has recently adopted a proposal for a Corporate Sustainability Reporting Directive (CSRD) which requires limited external assurance over reported information (European Commission, 2021). This proposal reinforces the need to understand the competitive assurance market.

The voluntary and unregulated practice of sustainability reporting has raised concerns about the reliability and credibility of the information provided (Boiral, 2018; Bouten et al., 2011). To address this issue, external independent verifications have grown considerably in the last decade. Among the world's largest companies, third-party assurance of sustainability reports has become standard practice, with most companies assuring their reports (e.g., 71\% of the G250) (KPMG, 2020).

Unlike a statutory financial audit, in which the market is controlled by accounting firms, the assurance of sustainability reports is a less mature and less organised market in which types of assurance providers compete for a share (Cohen and Simnett, 2014). The existence of this open, 
competitive and still-emerging market for the assurance of sustainability reports makes it an important area for research (Cohen and Simnett, 2014). Events - including mandating sustainability reporting in South Africa, Europe and Singapore as well as the United Nations Sustainable Development Conference in 2012 (United Nations Conference on Sustainable Development - Rio+20, 2012) - developed a pathway for a more sustainable world, which reinforced the need to investigate further the worldwide assurance practice of sustainability reports.

Prior studies of the assurance practices of sustainability reports are limited in scope and depth. First, most prior research concentrated on examining the assurance of sustainability reports in small samples of large global companies (Junior et al., 2014; Perego and Kolk, 2012). Further analysis is needed to allow researchers and practitioners to understand the global trends beyond this small group of companies. Assurance practices over sustainability reporting can vary considerably in terms of the assurance provider type, the scope and level of assurance and the standards used in the assurance engagement. Incomparability is a relevant concern because of the lack of clear guidance and the availability of different assurance standards (ACCA, 2015). The absence of unified standards for the assurance of sustainability reports has resulted in variations in assurance scope and in the methods used to perform the engagement (Cohen and Simnett, 2014).

Second, only a few prior studies have investigated the types of sustainability report assurance providers and they are not considering patterns at firm-level (e.g., firm type and listed status). Those studies mainly compared the sustainability reporting assurance practices between accounting and non-accounting firms (e.g., Clarkson et al., 2019; Farooq and de Villiers, 2019b; Hodge et al., 2009; Larrinaga et al., 2020; Peters and Romi, 2015). A more specific differentiation between the types of non-accounting assurers is central to allowing a much clearer overview of 
actual market practices. According to the Global Reporting Initiative (GRI) (2013b), accounting firms are currently the dominant sustainability assurance providers, mainly through Big-4 firms. Their global networks and their experience in financial auditing allow them a broad reach in the market. Other important assurance providers include engineering and consulting firms. Engineering firms are well known for their technical expertise and their understanding of complex processes. Consulting firms are generally smaller than other assurance providers and are usually locally-based with more subject-matter expertise to assure sustainability reports (GRI, 2013b).[1] This distinction between the different types of non-accounting firms is crucial to (i) allow a better understanding of the current assurance market, and (ii) provide a base for future studies. Additionally, prior research has studied the practice of assurance at the institutional level by analysing the increase in assurance practice and type of assurance provider by country (e.g., Junior et al., 2014) and in this study, we present the analysis of assurance practices consolidated by institutional-level factors (e.g., country and industry) and by firm-level factors (e.g., type and listed status). Finally, this study contributes to prior literature by performing a longitudinal analysis.

Using data from 12,783 companies globally from 1999 to 2017, this study provides an exploratory overview of the market and the practices of sustainability assurance around the world, adding to the literature reviews in this area, which have emphasised advances in research (Cohen and Simnett, 2014; Gillet-Monjarret and Rivière-Giordano, 2017; Gold and Taib, 2020; Maroun, 2018). The study concentrates on emerging trends from 2012, given the rise in the mandatory issuance of stand-alone sustainability reports by companies that emerged during this period. The study compares assurance providers' practices with respect to the standards used as well as the scope and level of assurance. Furthermore, it investigates companies' assurance practices in terms of consistency in providing an annual assurance over their sustainability reports. 
The contribution of this study is threefold. First, it provides an updated and broader mapping of sustainability reporting assurance practices globally. While prior research has concentrated on investigating sustainability practices on large companies (Junior et al., 2014; Perego and Kolk 2012) operating in specific jurisdictions (Reimsbach et al., 2017), this study examines a large sample of companies operating in several different countries and analyzing assurance practices at institutional-level (e.g., country and industry) and firm-level (e.g., type and listed status). This approach is important considering the recent significant increase in sustainability reports and mandatory requirements around the world (KPMG, 2020). A better understanding of how companies assure their sustainability reports is pivotal to support the development of practices and policies on external sustainability assurance. Second, this paper unveils hitherto unacknowledged companies' assurance patterns. The observed inconsistency in terms of the adoption of external assurance led us to find assurer switching to be a common practice among the examined companies ${ }^{[2]}$. These findings bring the attention of researchers and practitioners to assurance switching as a key aspect of the sustainability assurance market. Third, this study applies a unique classification for types of assurance providers that goes beyond the traditional accounting versus non-accounting assures. Prior studies suggest that assurance engagement, assurance quality and perceived assurance value might vary between different assurance providers (Michelon et al., 2019; Perego, 2009; Pflugrath et al., 2011). Without exploring those different non-accounting providers (i.e., engineering and consulting firms), results might be affected by a less refined classification of the assurance provider type. Our findings propose a classification of assurance providers that could be insightful in exploring those research questions. 
The remainder of this study is structured as follows. The next section reviews prior literature to provide an insight into sustainability report assurance and assurance providers. Section three discusses the research method used in the study. Section four presents data analysis and findings. Section five discusses our findings and provides suggestions for further research. Finally, section six concludes the study and presents some of its limitations.

\section{PRIOR LITERATURE}

\subsection{Assuring sustainability reports}

To improve the credibility of sustainability information, reliance on independent assurance has been growing (Edgley et al., 2010; Jones and Solomon, 2010). Managers can use sustainability reports to promote a more sustainable image of their companies (i.e., greenwashing) (Lyon and Maxwell, 2011; Walker and Wan, 2012). The assurance of sustainability reports increases users' confidence and their perceptions of information credibility (Boiral, 2018; Du and Wu 2019) and therefore engaging in sustainability assurance is believed to reduce greenwashing (Lyon and Maxwell, 2011). While assurance over sustainability report is still at an early stage and there are some questions raised about its reliability (Farooq and De Villiers, 2019a), studies suggest that assurance is essential to ensure a certain level of reliability, and stakeholders perceived assured report as more reliable than non-assured once (Cheng et al., 2015; Reimsbach et al., 2017).

In addition to increasing reliability, prior studies found other factors to be associated with the voluntary adoption of assurance over sustainability reports. Simnett et al. (2009) indicate that companies with a higher need to build their corporate reputation are more likely to have their sustainability reports assured. Kolk and Perego (2010) examine the effect of country-level institutional factors on the voluntary adoption of assurance over sustainability reports by a sample of G250 companies from 1999 to 2005 . Their findings indicate that companies in stakeholder- 
oriented countries are more likely to assure their sustainability reports than companies in shareholder-oriented countries. Shareholder-oriented countries are those in which companies are seen as instruments for shareholder value creation; other stakeholders are less relevant. Liao et al. (2018) find that some board characteristics, such as board size, the presence of a female director and separation between the chairperson and the CEO position, increase the likelihood of companies assuring their sustainability reports.

In order to obtain an overview of the current trends in the assurance of sustainability reports, we first analyse institutional and firm-level characteristics in terms of assurance adoption. Second, we analyse market distribution among different assurance providers and their practice in terms of scope, level of assurance and standards used. Finally, we document companies' consistency in term of assurance adoption and their choice of assurance provider.

The main concern in the assurance process of sustainability reports is the absence of a generally accepted standard to guide practitioners. The standard frameworks mostly used by assurance providers are the International Standard for Assurance Engagements (ISAE 3000) issued by The International Auditing and Assurance Standards Board (IAASB), and the AA1000 AccountAbility Standard (AA1000 AS), issued by AccountAbility (Fuhrmann et al., 2017).

The adoption of these different standards has been associated with variations in assurance engagement. During an assurance engagement, an agreement must be made regarding the scope and level of assurance. Scope indicates which part of the report is covered in the assurance engagement (e.g., the entire report or sections) (AccountAbility, 2008b; IAASB, 2013). The level of assurance indicates the degree of certainty the assurance provider has that the report is free from error (e.g., limited/moderate or reasonable/high) (AccountAbility, 2008b; IAASB, 2013). 
Both standards involve a risk assessment process and a test procedure to support an opinion on the subject matter of the engagement. Unlike the ISAE 3000, the AA1000 AS provides two types of assurance engagements. A type 1 engagement evaluates the extent of the organisation's adherence to all AA1000 AccountAbility Principles (AA1000 APS) ${ }^{[3]}$ to ensure the way an organisation manages sustainability performance but it does not verify the reliability of the reported information (AccountAbility, 2008a). A type 2 engagement extends type 1 by including an evaluation of the organisation's adherence to AA1000 APs and an evaluation of the reliability of the information provided (AccountAbility, 2008a).

Both standards have two levels of assurance, namely, reasonable/high or limited/moderate. A reasonable/high assurance requires a higher extent of investigation and evidence than a limited/moderate assurance. However, the difference in the extent needed for an assurance engagement to be considered reasonable/high rather than limited/moderate is unclear (Farooq and de Villiers, 2019b), and assurance providers rely significantly on their professional judgement to determine materiality (Moroney and Trotman, 2016). Additionally, the differences between assurance providers' definition of materiality have been recognised as a major concern (Edgley et al., 2015).

The absence of a single set of generally accepted standards has resulted in inconsistent sustainability reporting assurance engagements, including the scope and level of assurance provided (Manetti and Becatti, 2009). Therefore, in this paper, we also examine the adoption of different standards by sustainability reporting assurers and the effects of such adoption on the assurance practices. 


\subsection{Types of assurance providers}

The lack of specific legislation on assurance engagement and the competencies required from the assurance providers of sustainability reporting has resulted in different types of firms providing assurance services. Previous studies have broadly classified assurance providers into two groups: accounting firms and non-accounting firms (Manetti and Toccafondi, 2012; O’Dwyer et al., 2011). The main accounting providers are the Big- 4 accounting firms, which have experience and competence in providing financial assurance services globally (Simnett et al., 2009). However, several researchers argue that social and environmental specialists have a better understanding of the subject matter (Cohen and Simnett, 2014). According to Perego (2009), an assurance statement issued by one of the Big-4 accounting firms ranks lower in terms of the quality of the recommendations and the opinions provided than one issued by non-accounting assurers. Therefore, companies issuing sustainability reports are left to choose between accounting firms, which provide high-quality assurance in terms of procedures and reporting format and social and environmental experts, who provide high-quality assurance in terms of recommendations.

Following the prior classification of assurance providers (CorporateRegister 2008), Perego and Kolk (2012) briefly address different types of assurance providers including accounting firms, consulting firms, specialists, certification bodies, academic institutions and stakeholder panels. Perego and Kolk (2012) examines accounting versus non-accounting firms where non-accounting include engineering firms, specialist consulting firms and certificate. Other studies have considered the same classification of accounting versus non-accounting firms, where the nonaccounting category includes only engineering and certification firms (Liao et al., 2018). GRI is also highly used among researchers as a reference for the type of assurance provider (e.g., Simnett et al., 2009). GRI only considers independent third-party assurance types and it classifies them 
into three different types of assurance providers: accounting, engineering and consulting. As observed in previous literature, the research practice of examining the classification of assurance providers is not consistent. Figure 1 depicts the different types of assurance providers.

\section{[Insert_Figure_1_about_here]}

Research evidence has produced mixed results about the perceived credibility of assurance providers. For example, Hodge et al. (2009) find weak evidence that users of sustainability reports place greater reliance on an assurance opinion provided by professional accounting firms than that provided by consulting firms. Pflugrath et al. (2011) examine a sample of 106 financial analysts from Australia, the UK and the US, and find that financial analysts from the US perceive accounting firms as more credible assurers, whereas analysts from Australia and the UK show little difference in the perception of enhanced credibility between different types of assurers. Clarkson et al. (2019) suggest that the capital market only values assurance when it is provided by Big-4.

While the literature recognises the factors associated with companies' decisions to voluntarily assure their sustainability reports (Darnall et al., 2009; Herda et al., 2014), there is weak evidence on the factors associated with companies' decisions over which type of assurance provider to select. Among such factors are the legal environment and the industry. Simnett et al. (2009) find that companies operating in weak legal environmental countries (e.g., Mexico, China or Turkey) or in environmental risk industries (e.g., mining, production or utilities) do not necessarily appoint a member of the auditing profession to assure their sustainability reports. Hence, the researchers suggest that the decision to assure sustainability reports is an important one for companies in industries needing to enhance their credibility and the decision about the type of assurance provider to employ is less important. Additionally, they find that companies operating 
in stakeholder-oriented jurisdictions are more likely to choose an accounting firm as their assurance provider than companies operating in shareholder-oriented jurisdictions (Simnett et al., 2009). Contrarily, Kolk and Perego (2010) find that companies operating in shareholder-oriented countries usually choose large accounting firms as their assurance providers.

The lack of significant findings in the literature regarding the main determinants of the choice of assurance provider could be explained by the limited classification used in prior research (grouping different types under non-accounting groups). The non-accounting category includes both engineering and consulting firms (GRI, 2013a). Engineering firms have a global network and have been at the top of the list for providing sustainability reports assurance. For example, DNV GL is a leading assurance provider operating in more than 100 countries (World Business Council for Sustainable Development, 2016). Contrarily, consulting firms, generally smaller in size than other assurer types, are mostly local and have a greater knowledge of the respective local stakeholders (GRI, 2013a). The distinction between engineering and consulting firms is crucial for explaining companies' choices between different types of assurance providers. The choice between engineering and consulting firms could be driven by different reasons. By applying the three classifications of assurance providers, instead of the dichotomous approach (e.g., accounting versus non-accounting), this study is able to reveal patterns not previously observed. In this study, we adopt GRI classification by considering three types of independent external assurance (i.e., accounting, engineering and consulting). We consider these three types as they are under the same level and we do not consider subtypes under each group (e.g., Big-4 under accounting group) as we do not have further details of what subgroups are under engineering and consulting firms.

\subsection{Trend analysis of assurance practices}


While most studies have examined the demand for sustainability reports assurance and the quality of the assurance provided, little research has considered patterns or performed trend analyses. Junior et al. (2014) provide a descriptive analysis of global companies' (G500) assurance practices and suggest a steady increase in their issuance of sustainability reports over the past decade. However, their study suggests that the number of assured sustainability reports has not increased significantly, which may indicate little change in the perceived value of assuring those reports. Additionally, the authors argue that a more comprehensive view of the practices would require extending the analysis to a much larger sample of companies and countries (Junior et al., 2014).

Perego and Kolk (2012) analyses how patterns of sustainability report assurance by multinational corporations have evolved by examining a panel of the G250. Their findings show that institutional forces (e.g., legal, environmental and stakeholder pressures) appear to control multinational corporations' activities. However, their assurance adoption patterns and adherence to standards vary considerably. Perego and Kolk (2012) classify the adoption patterns of assuring sustainability reports into categories: early adopters, late adopters, followers, laggards and nonadopters. Within each group, they differentiate between consistent and non-consistent adopters. Perego and Kolk (2012) find that early adopters relied on accounting assurers and had a diminishing reliance on non-accounting assurers. Finally, their study indicates a consistent pattern in the choice of assurance provider in which switches from assurance providers were unusual.

In this study, we concentrate on exploring the consistency of providing assured sustainability reports at two levels. First, we determine whether the company assures its reports over the tested periods. Second, we determine whether the company hires the same assurer over the tested period. If the company changes its assurer, an assurer switch results. Assurer switch refers to the situation in which companies change their assurance provider over the tested period. 
The practice of changing the assurance provider needs to be investigated, as assurance switching might prevent a clear picture of companies' performance from emerging over time (Ball et al., 2000). Such an analysis will lay the groundwork for future research.

The limited sample used in prior studies and their concentration on large companies (e.g., G500) (Junior et al., 2014; Manetti and Toccafondi, 2012; Perego and Kolk, 2012) motivated our study to consider a holistic approach. New developments including the mandatory reporting requirement in different countries (e.g., European Union, South Africa and Singapore) call for a broad and updated mapping of the current practices in this area. Hence, a more profound and updated examination of the current assurance practices should include different types of companies: large, small and medium-sized enterprises, listed and non-listed companies and nonprofit organisations. Additionally, in this study, we are performing a longitudinal analysis.

\section{METHODOLOGY}

The study uses the GRI database obtained in September 2020. The GRI database stores and tracks companies' sustainability reports and associated organisational data for reports published after 1999. Given the scope of our research, which is restricted to the assurance practices and trends of companies that produce sustainability reports, we believe the GRI data to be adequate as it allowed us to access companies that are assuring their sustainability reports. GRI data is self-reported by companies. To examine the reliability of the data, we cross-reference a sample of 1,388 companies in GRI with the Thomson Reuters Asset4 database. Companies reporting that they provide assurance in GRI are a $98.6 \%$ match with the observations in the Asset4 database. ${ }^{[4]}$ We also worked on reviewing the data to ensure consistency in companies' reported information.

The analysis of the time difference between companies' first sustainability reports and their first adoption of external assurance relies on a sample including a panel of 13,028 companies that 
issued sustainability reports during the period 1999 to 2017 . All other analyses are applied to a panel of 12,783 companies over a six-year period (2012-2017). Chi-square tests have been conducted to examine the significance of the change between periods.

The sample (2012-2017) represents companies from different regions, with different listed status and size. The companies are from Africa (6\%), Asia (30\%), Europe (36\%), Latin America and the Caribbean (13\%), Northern America (11\%) and Oceania (3\%). The sample includes listed $(67 \%)$ and non-listed $(33 \%)$ companies of three sizes: large companies $(65 \%)$, multinational enterprises (MNEs) (28\%) and small and medium-sized enterprises (SMEs) (7\%). ${ }^{[5]}$

\section{DATA ANALYSIS}

This section presents the main findings of this study. First, it presents the current sustainability assurance trends at the institutional and firm levels. Next, it examines the market distribution for types of assurance providers, assurance standards, assurance scope and the level of assurance. Finally, it analyses the issue of consistency in the assurance of sustainability reports and the practice of assurance switching.

\subsection{Sustainability assurance trends}

Table 1 depicts the relationship between the issuance of sustainability reports and assurance growth. As shown in the table, from 2012 to 2017, the number of companies issuing sustainability reports increased by $56.2 \%$. Additionally, the number of assured sustainability reports increased by $20.1 \%$. The growth of the sustainability reports is greater than the growth of the assured reports, which suggests that companies are less likely to assure their sustainability reports when they issue them for the first time.

$$
\text { [Insert_Table_1_about_here] }
$$


Table 2 depicts the number of sustainability reports and the number of assured sustainability reports by region. The growth of sustainability reports and assured sustainability reports varies considerably across regions. The increase in those reports is significant in Africa, which is expected as the JSE requires all listed companies to produce an integrated report (ACCA, 2015). In addition, there is a significant increase in report numbers in Asia, Europe and Latin America and the Caribbean. Assured sustainability reports have not increased substantially in numbers among regions except for Asia. Therefore, the demand for assured sustainability reports is still in its early stages. The significant increase in Asia might be explained by the sustainability programme presented by the Association of Asian Academics of Science "Toward a Sustainable Asia” (AASA, 2010).

\section{[Insert_Table_2_about_here]}

Table 3 presents the number of sustainability reports issued and the number of assured sustainability reports among industries. The financial services industry leads in the production of sustainability reports, followed by energy and food and beverage. However, the number of assured sustainability reports has not increased significantly for any specific industry.

\section{[Insert_Table_3_about_here]}

Table 4 depicts the number of sustainability reports and the number of assured sustainability reports by company type, listed status and size. The results show a significant increase in the production of sustainability reports among private and state-owned companies. Additionally, the results show a significant rise in assured sustainability reports by private companies and a decrease among state-owned companies. Sustainability reports increased substantially for both listed and non-listed companies. However, a significant increase in assured reports is observed only among listed companies. Furthermore, the increase in the number of 
sustainability reports among large companies, MNEs and SMEs is significant. Assured reports increased very significantly only among MNEs.

$$
\text { [Insert_Table_4_about_here] }
$$

\subsection{The time companies take to issue their first sustainability reports}

Table 5 shows the time difference between companies' first sustainability reports and their first external assurance by region and company size. The time difference between the issuance of the first sustainability report and the first assurance is 2 years, on average. The time difference varies within both regions and company size. For example, Latin American and Caribbean companies, on average, assure sustainability reports in less than 2 years, whereas Northern American companies take nearly 4 years to assure their sustainability reports. Additionally, Table 5 shows that SMEs, on average, assure sustainability reports in less time than larger companies and MNEs.

$$
\text { [Insert_Table_5_about_here] }
$$

\subsection{Market distribution for types of assurance providers}

Table 6 presents the growth of sustainability report assurance by types of assurance providers. As observed in the table, accounting firms dominate the market. This result is expected, given that accounting firms are usually large-sized firms with global networks. These considerations play a significant role in companies' choice to assure financial and non-financial reports. The number of sustainability reports assured by engineering firms has significantly grown in recent years. In comparison with the two other assurer types, assurance of sustainability reports by consulting firms presented a decrease.

$$
\text { [Insert_Table_6_about_here] }
$$


Table 7 presents the market distribution between assurance providers of assured sustainability reports by region, company type and industry. Assurance provided by accounting firms presents an increase in most regions with a significant increase only in Asia. In Asia, assurance by engineering firms has increased substantially. Consulting firms have reduced their market share in all regions except Latin America and the Caribbean. Thus, the results suggest that region is a relevant factor in the distribution of the sustainability reports assurance market. In terms of the choice of assurance provider by type of company, Table 7 depicts a statistically significant increase in the number of private companies assured by accounting and engineering firms, while the number of private companies assured by consulting firms has decreased. Finally, as observed in Table 7, accounting firms have a higher market share in all industries. Their presence has increased mainly in food and beverage, financial services and real estate. The market share controlled by engineering firms is higher in the financial services and chemical industries. The market share controlled by consulting firms has decreased among most industries.

\section{[Insert_Table_7_about_here] \\ 4.4 Assurance standards, assurance scope and level of assurance}

Table 8 depicts the use of assurance standards, scope and level of assurance. Table 8 Panel A shows that the use of the ISAE 3000 and AA1000 has increased significantly. Table 8 Panel B shows the use of assurance standards by the type of assurance provider. The results confirm previous literature indicating that the ISAE 3000 is the standard preferred by accounting firms (Mock et al., 2007; O'Dwyer and Owen, 2007; Perego, 2009). There is a difference in the standard used by non-accounting firms. The use of the AA1000 and ISAE 3000 among engineering firms has increased substantially. However, the use of AA1000 decreased and the use of ISAE 3000 increased among consulting firms. 
Table 8 Panel $\mathrm{C}$ displays the assurance scope and the level of assurance by the type of assurance provider. The results show that $39 \%$ of accounting firms provide an assurance that applies to the entire report. Additionally, the results reveal that $61 \%$ of engineering and $54 \%$ of consulting firms provide an assurance that covers the entire sustainability report. These results might indicate that accounting firms are more cautious about providing assurance over the entire report while engineering firms are more likely to do so. Additionally, accounting firms are less likely to provide a reasonable/high level of assurance. Only $8 \%$ of the assurance provided by accounting firms is reasonable/high, while the level of reasonable/high assurance provided by engineering and consulting firms was $16 \%$ and $12 \%$, respectively.

$$
\text { [Insert_Table_8_about_here] }
$$

\subsection{Consistency in assuring sustainability reports}

Figure 2 depicts a tree-map for companies' classification based on their issuance of sustainability reports and assurance of reports. Out of the 12,783 companies in our sample, $15.2 \%$ issued an annual report every year over the examined period. Those companies are consistent reporters. The majority of consistent reporters $(46.5 \%)$ are consistent non-assurers. Consistent non-assurers are companies that did not assure their reports during the same six-year period. The second highest group is non-consistent assurers (36.2\%). Non-consistent assurers are companies that assured their report in one or more years but not in a subsequent period. The lowest group is consistent assurers $(17.3 \%)$. Consistent assurers are companies that assured all of their reports over the examined period. Finally, $63.0 \%$ of consistent assurers have the same assurance provider during the period, which means $37.0 \%$ of the consistent assurers subgroup underwent an assurance provider switch.

$$
\text { [Insert_Figure_2_about_here] }
$$




\subsection{Assurer switch}

In this paper, we define assurer switch as a company's change of assurance provider from one type to another. For example, if a company issues a sustainability report assured by an accounting firm in 2013 and issues a sustainability report assured by an engineering firm in 2014, the assurance provider has been switched. We also consider a switch to have occurred if a company issues an assured sustainability report in one year and issues another sustainability report in the following year that is not assured. [6]

Table 9 shows the percentage of switches happening in 2012/2013, 2013/2014, 2014/2015, 2015/2016 and 2016/2017. Each year offers five possibilities for a switch. First, the company switches from having assurance to no assurance. Second, a company changes their assurance provider to the accounting type. Third, a company changes their assurance provider to the engineering type. Fourth, a company changes their assurance provider to the consulting type. Fifth, a company switch from no assurance to having an assurance.

\section{[Insert_Table_9_about_here]}

Over the tested period, 1,525 switches occurred, including the switch from assured report to non-assured and from non-assured to an assured report (see Table 9). Four hundred and eighteen switches occurred between the three types of assurance providers, including switches from one type of assurance provider to another. Table 9 shows a decrease in the switch to accounting firms in the last switch period, but an increase in the switch to engineering firms. Additionally, the highest percentage of switches in the last switch period is to engineering and consulting firms, which is surprising considering the scant increase of the consulting market share (see Table 5). These results might indicate that consulting firms are more likely to assure the reports of 
companies that had prior assurance than they are to assure reports of companies that are assuring their reports for the first time.

\section{DISCUSSION}

Sustainability reports are becoming a common practice among companies, and many countries mandate their issuance. Nevertheless, the results of this research show a significant variation in the growth of the assurance of sustainability reports among different regions, industries, company types, listed status and size. For instance, prior studies suggest companies' size is associated with companies' voluntary decision to assure their sustainability report (Simnett et al., 2009). Perego and Kolk (2012) find that assured sustainability reports among MNEs increased significantly from 1999 to 2008 . Our results extend those findings by showing a significant increase in the assurance of sustainability reports among MNEs for the period from 2012 to 2017 . However, the results reported in this research do not show a significant increase in assurance among large companies and SMEs. The growth in assuring sustainability reports lags behind the growth in issuing sustainability reports. This finding indicates that the practice of assuring sustainability reports is still emerging, and our understanding of the practice is incomplete. The perceived value of assurance seems to be questioned, as suggested by a few researchers (Birkey et al., 2016; Boiral et al., 2018; Coram et al., 2009). We still know little about the extent to which different groups of stakeholder value assurance and whether its perceived value is affected by who provides the service (e.g., accounting or engineering firms). Furthermore, it is unclear whether the perceived value differs across regions, industries, company types, status and company size. Assimilationcontrast theory suggests that individuals (e.g., stakeholders) use their current beliefs as internal reference points to which the actual organisation's attempt is compared (De Bruyn and Prokopec, 2017; Sherif et al., 1958). Maroun (2019) suggests that assurance is important for meeting 
stakeholders' expectations of external verification. If intended users of sustainability reports believe that a company of certain characteristics (e.g., large or operating in an environmentally sensitive industry) should provide external assurance and the company does not provide it, credibility concerns might arise (e.g., greenwashing). While there are some experimental studies focusing on behavioural aspects (e.g., Vazquez et al., 2018), more behavioural studies that investigate such phenomena would be helpful.

Additionally, studies could expand the understanding of the role of external factors on internal assurance practices. In this vein, consideration of different institutional factors (e.g., country-level factors and institutional investors) could provide fruitful insights. A recent study by Isidro et al. (2020) investigates new factors that "illustrate one method to deal with the observed co-dependency's of countries' economic, political, regulatory, and social characteristics". Their results show that institutional factors are positively and significantly associated with accounting outcomes (i.e., financial report quality). The consideration of such factors might contribute to extending our limited understanding of companies' assurance practices. The same factors could also be applied to investigating companies' choice of assurance provider. The relationship between firms and stakeholders that are for instance examined by the stakeholder (Darnall et al., 2009) or agency (Liao et al., 2018) theories, could provide the necessary framework for studies in this area.

The time difference between a company's first sustainability report and its first assured sustainability report indicates that companies are unlikely to assure their reports when they are first issued. The results of our study reveal that the time companies take to assure their sustainability reports after they are first issued varies based on region and company size. Companies located in Africa, Northern America and Oceania are more likely to take longer to assure their reports (see Table 5). Additionally, the result shows that SMEs take a shorter time to 
assure their reports in comparison with large companies and MNEs. Previous research has shown that assuring a sustainability report is a way of validating the information provided in the report (Simnett et al., 2009), which might affect investors' and other stakeholders' decisions (Cheng et al., 2015; Reimsbach et al., 2017). However, research has not addressed the timing for assurance decisions. It is still unclear why certain companies take longer than others to assure sustainability reports and how this decision affects companies and stakeholders. Assurance is used as a credibility-enhancing mechanism (Maroun, 2019; Pflugrath et al., 2011; Wong and Milington, 2014). Thus, providing a sustainability report without an external assurance might lead intended users to believe that such a report is used as an impression management tool to communicate a more sustainable image. Studies that investigate the time taken to assure a sustainability report would assist companies to understand its effect on stakeholders' perceptions and performance. Legitimacy theory has the potential to contribute to this stream of research as it provides a framework that explains how companies can use external assurance to meet stakeholders' perceptions of what they understand to be a legitimate practice.

Our results suggest that the choice of an assurance provider is not random. The distribution among the three types of assurance providers differs by region, industry and type of corporation. The regional differences could be the result of the assurance provider's presence in the region. For example, Big-4 accounting firms are well known and have international branches, while consulting firms are mostly local businesses. Engineering firms, on the other hand, are more likely to compete with Big-4 accounting firms, as the former are growing significantly in the market: see, for example, DNV GL and Bureau Veritas. The significant increase in the assurance provided by accounting and engineering firms could raise questions about the perceived value of the assurance provided by consulting firms. However, a more careful analysis of the market shows that in recent 
years several of these smaller consulting firms have been acquired by larger accounting and engineering firms. For instance, in 2015 KPMG Australia acquired the human rights consultancy Banarra. Despite those events, the observed patterns in the market share among different types of assurance providers indicate that the choice of assurance provider is an important decision for companies.

The finding of the study reveals the importance of non-accounting assurance providers, including engineering and consulting firms. The fast growth of engineering firms signals high competition in the assurance market. The increase in consulting firms' assurance is scant; however, the switch towards consulting firms is higher than the switch towards accounting firms in the last switch period. This finding might indicate a preference for consulting firms. Additionally, the variation in the result between engineering and consulting firms shows the importance of considering three types of assurance providers instead of grouping engineering and consulting firms into one type (i.e., non-accountant), which has historically been the practice in academic studies (Simnett et al., 2009; Manetti and Toccafondi, 2012; Perego, 2009). Future qualitative studies could provide fruitful insights by analysing how companies make their assurance provider choice. Interview approach with decision-makers in companies could also yield valuable insights. The effect of the cost of sustainability assurance is one of the ambiguous areas, thus a study investigating the impact of cost considerations on the assurance decision and the choice of assurance providers could potentially provide a better understanding. Furthermore, companies' assurance provider choice might be influenced by the quality of the assurer or its availability. Therefore, there are different motives for addressing the question of why companies choose a certain type of assurance provider over others. Stakeholder, agency, institutional and contingency 
theories could be suitable theoretical perspectives with which to explore the factors that influence companies' decisions regarding assurance and the choice of assurance provider.

We observe that switching is a common practice. Switching from assured to non-assured reports could lead to the risk of discontinuation. Such change and variation might have negative implications for companies, as they provide mixed signals to stakeholders (Reimsbach et al., 2017). Additionally, the practice of switching assurance providers in consecutive years may limit the possibility of companies acting on recommendations given by previous assurance providers (Ball et al., 2000). Companies' decision to switch is an under-researched practice. During the period examined in this study, the percentage of companies switching from assured to non-assured reports increased from $19 \%$ to $41 \%$, while the switch from non-assured to assured reports decreased from $52 \%$ to $34 \%$. Despite the different initiatives promoting external assurance (e.g., IIRC and GRI), further emphasis is needed on the value of assurance. If the perceived value of assurance among intended users is affected by who provides such a service, then what impact could the practice of changing assurance provider over time impose? Or if the switch is from an assured to a non-assured report, what kind of signal could this send to stakeholders and how will they interpret such a signal (risk of discontinuation)? Signalling theory is helpful to address such questions as it provides a framework for understanding how two parties (e.g., organisation and intended users) address information asymmetries. For example, management may signal their higher reputation through hiring a high-reputation auditor (Bavlers et al., 1988).

We observe a variation in the assurance standard used as well as in the assurance scope and level among the three types of assurance providers. The results indicate an increasing trend towards the use of the ISAE 3000 by non-accounting assurers. Michelon et al. (2019) find that assurance providers use sustainability restatement as a mechanism to legitimise the sustainability 
assurance market. Therefore, the use of the ISAE 3000 by non-accounting firms might be an attempt to legitimise their services. The variation in assurance practices increases the need to regulate the external assurance market by setting clear guidelines and standards that define the required skills and backgrounds of external assurers. Additionally, the study reveals that engineering firms are more likely to provide assurance over the entire report and to provide reasonable/high levels of assurance, compared to accounting and consulting firms. Future studies could also investigate why there is a significant increase in the number of non-accounting firms using the ISAE 3000 standard. Prior research suggests that accounting firms provide higher quality in terms of the reporting format and assurance engagement procedure (Perego, 2009) and accounting firms are more likely to use ISAE 3000 standards (O'Dwyer and Owen, 2007; Mock et al., 2007; Perego, 2009). Therefore, it might be that the increase in the use of the ISAE 3000 by non-accounting assurers is an attempt by those firms to improve the perception of the quality of their assurance engagement and the reliability of their services. This could convert into increased legitimacy.

Kolk (2010), while examining a sample of large companies, suggests that companies that consistently provide sustainability reports are leading in the adoption of assurance. However, our results show that the majority of companies that provide sustainability reports consistently do not provide any assurance over the tested period. This result shows the importance of examining assurance practices from a broader perspective, which includes a larger sample containing companies with different characteristics. Additionally, these findings raise questions about the reasons underlining the lack of assurance among companies that are committed to providing a sustainability report. External assurance is one way to ensure sustainability report reliability and it might be the case that those companies are using different credibility-enhancing mechanisms (e.g., 
internal audit or stakeholder panel). Companies could use such mechanisms to create trust between companies issuing sustainability reports and the intended users of those reports. Do such mechanisms act as a substitute or are they complementary to independent external assurance? Signalling theory might be helpful for addressing such questions by providing a framework to understand how companies might use certain mechanisms to signal the reliability of their sustainability reports (Balvers et al., 1988). Table 10 summarizes the issues discussed above.

[Insert_Table_10_about_here]

\section{CONCLUSION}

Overall, the results of this study provide insights that regulators can employ to develop future regulations on sustainability reports. For example, the EU Non-Financial Reporting Directive mandates that companies provide a stand-alone sustainability report, but it does not mandate the assurance of the report (European Parliament, 2014). The success of such regulation relies upon companies providing valid and reliable information that can be trusted by stakeholders. Assurance might assist regulators in influencing companies to provide useful information for decision making rather than using sustainability reports as tools for impression management (Walker and Wan, 2012).

Research on the assurance of sustainability reports is still emerging, and further studies are needed to explore and examine the practice of assurance. The results of the market distribution among the three types of assurance providers reveal the importance of considering a specific classification rather than grouping different types under the collective heading of non-accountant firms. Further research could examine the differences in assurance engagement among these assurance providers. Our results depict differences in the standard use, the scope and the level of 
assurance between engineering and consulting firms. By considering different types of assurers within the non-accounting group, future research might extend previously reported results.

In this study, we examine independent, third-party assurance, which is similar to traditional financial auditing but not yet at the same level of maturity. However, other forms are available for the assurance of sustainability reports. The other two most common forms are stakeholder panel and expert opinion (De Beelde and Tuybens, 2015). Although previous studies have included stakeholder panels and expert opinion as forms of assurance (Perego and Kolk, 2012), those studies have not examined qualitatively the process of those forms of assurance. Additionally, the extent to which companies use these different forms of assurance as complements or substitutes for independent, third-party assurance remains unclear. One of the limitations of this study is that it relies on GRI data and its report on companies' formalised sustainability practices. The study does not consider companies use different forms of communication and media channels (e.g., social media) to inform and legitimise their sustainability practices. Future studies examining different ways companies use to communicate their sustainability performance will complement our findings on the mechanisms used to ensure information reliability and credibility. Another limitation of this study is the methodology. Using descriptive analysis allows us to understand the assurance market trends, however, it does not allow us to examine associations between institutional / firm level factors and companies' choice of assurance provider or their decision to change the assurance provider. Therefore, further studies exploring such associations will complement our findings and enhance our understanding of companies' choice of assurance provider.

Finally, in this study, we observe the practice of assurer switching. Our exploratory study allows us to investigate switching trends. Further studies could expand our findings by 
investigating the drivers of switching. Prior studies have investigated the factors driving companies' decisions to voluntarily assure their sustainability reports (Kolk and Perego, 2010; Liao et al., 2018; Simnett et al., 2009), but there is a lack of understanding about the choices of assurance providers and the consistency of the assurance decisions across years. Prior studies examine the factors influencing companies to change their auditor, in a phenomenon known as "auditor switch" (Chen and Zgou, 2007; Hudaib and Cooke, 2005); the same factors could be applied to examining assurer switch.

\footnotetext{
${ }^{1}$ The typology of accounting (e.g., Ernst \& Young and KPMG), engineering (e.g., Bureau Veritas and DNV) and consultancy (e.g., Net Balance) firms does not imply that such firms only dedicate their activities to the specific activities of accounting, engineering and consulting respectively. For instance, it is well recognised that a significant part of the revenues of Big-4 accounting firms comes from consulting activities. However, the above classification allows us to examine market preferences and trends by understanding the specificities of these different types of firms. ${ }^{2}$ We consider assurance switch when companies change their assurance provider from one type to another or when change their assurance status from assured to non-assured. This definition does not account for switch that occur within the same type.

${ }^{3}$ The three principles are "Inclusivity (People should have a say in the decisions that impact them), Materiality (Decision makers should identify and be clear about the sustainability topics that matter), [and] Responsiveness (Organisations should act transparently on material sustainability topics and their related impacts)" (AccountAbility, 2008a), and a fourth principle was recently added: "Impact (Organisations should monitor, measure and be accountable for how their actions affect their broader ecosystems)" (AccountAbility, 2018).

${ }^{4}$ To further examine the reliability of GRI data, we randomly selected 20 companies in our sample and checked the information on their sustainability reports with the information in GRI. Manually collecting information for several years, with special attention to the type of assurance provider, we found $94.0 \%$ match with GRI data.

${ }^{5}$ Companies are considered as SME if headcount is less than 250 and as large enterprise if the headcount is equal to or more than 250. MNE are companies that have a headcount equal to or more than 250 and are multinational.

${ }^{6}$ Such definition excludes switches within assurers of the same type (e.g., different accounting firms).
} 


\section{References}

Association of Chartered Certified Accountants (ACCA) (2015), "The challenges of assuring integrated reports: Views from the South African auditing community”, Association of Chartered Certified Accountants, available at: https://www.accaglobal.com/content/dam/ACCA_Global/Technical/integrate/ea-southafrica-IR-assurance.pdf.

AccountAbility (2008a), “AA1000 Accountability principles standard 2008”, AccountAbility, available at: https://www.accountability.org/wpcontent/uploads/2016/10/AA1000APS_english.pdf.

AccountAbility (2008b), “AA1000 Assurance Standard 2008”, AccountAbility, available at: https://www.accountability.org/wp-content/uploads/2016/10/AA1000AS_english.pdf.

AccountAbility (2018), “AA1000 Accountability 2018 principles”, AccountAbility, available at: https://www.accountability.org/wpcontent/uploads/2018/05/AA1000_ACCOUNTABILITY_PRINCIPLES_2018_Single_Pag es.pdf.

Association of Academies of Sciences in Asia (AASA), (2010), "Green transition and innovation in Asia”, Association of Academies of Sciences in Asia, Berlin, Heidelberg: Springer. https://doi.org/10.1007/978-3-642-16675-4_5

Ball, A., D. Owen, L., and Gray, R. (2000), "External transparency or internal capture? The role of third-party value to corporate environmental reports", Business Strategy and the Environment, Vol. 9 No. 1, pp. 1-23. https://doi.org/10.1002/(SICI)10990836(200001/02)9:1\%3C1::AID-BSE227\%3E3.0.CO;2-H

Balvers, R. J., McDonald, B., and Miller, R. E. (1988), "Underpricing of new issues and the choice of auditor as a signal of investment banker reputation” The Accounting Review, Vol. 63 No. 4, pp. 605-622. JSTOR, www.jstor.org/stable/247902.

Birkey, R.N., Michelon, G., Patten, D.M., and Sankara. J. (2016), "Does assurance on CSR reporting enhance environmental reputation? An examination in the US context", 
Accounting Forum, Vol. 40 No. 3, pp. 143-152.

https://doi.org/10.1016/j.accfor.2016.07.001

Boiral, O., Heras-Saizarbitoria, I., Brotherton, M.C., and Bernard. J. (2018), "Ethical issues in the assurance of sustainability reports: Perspectives from assurance providers", Journal of Business Ethics, Vol. 159 No. 4, pp. 1111-1125, https://doi.org/10.1007/s10551-018-38403

Bouten, L., Everaert, P., Van Liedekerke, L., De Moor, L., and Christiaens, J. (2011), "Corporate social responsibility reporting: A comprehensive picture?", Accounting Forum, Vol. 35 No. 3, pp. 187-204. https://doi.org/10.1016/j.accfor.2011.06.007

Chen, K.Y., and Zhou. J. (2007), "Audit committee, board characteristics, and auditor switch decisions by Andersen's clients", Contemporary Accounting Research, Vol. 24 No. 4, pp. 1085-1117. https://doi.org/10.1506/car.24.4.2

Cheng, M.M., Green, W.J., and Ko. J.C.W. (2015), "The impact of strategic relevance and assurance of sustainability indicators on investors' decisions", Auditing: A Journal of Practice \& Theory, Vol. 34 No. 1, pp. 131-162. https://doi.org/10.2308/ajpt-50738

Clarkson, P., Li, Y., Richardson, G., and Tsang, A. (2019), "Causes and consequences of voluntary assurance of CSR reports", Accounting, Auditing \& Accountability Journal, Vol. 32 No. 8, pp. 2451-2474. https://doi.org/10.1108/AAAJ-03-2018-3424

Cohen, J.R., and Simnett, R. (2014), "CSR and assurance services: A research agenda", Auditing: A Journal of Practice \& Theory, Vol. 34 No. 1, pp. 59-74. https://doi.org/10.2308/ajpt-50876

Coram, P.J., Monroe, G.S., and Woodliff, D.R. (2009), "The value of assurance on voluntary nonfinancial disclosure: An experimental evaluation", Auditing: A Journal of Practice \& Theory, Vol. 28 No. 1, pp. 137-151. https://doi.org/10.2308/aud.2009.28.1.137

CorporateRegister, (2008), "The CSR Assurance Statement Report”, CorporateRegister: London, UK: CorporateRegister.com

Darnall, N., Seol, I., and Sarkis. J. (2009), "Perceived stakeholder influences and organizations' use of environmental audits", Accounting, Organizations and Society, Vol. 34 No. 2, pp. 170-187. https://doi.org/10.1016/j.aos.2008.07.002 
De Beelde, I., and Tuybens. S. (2015), "Enhancing the credibility of reporting on corporate social responsibility in Europe", Business Strategy and the Environment, Vol. 24 No. 3, pp. 190-216. https://doi.org/10.1002/bse.1814

De Bruyn, A. and Prokopec, S. (2017), “Assimilation-contrast theory in action:

Operationalization and managerial impact in a fundraising context", International Journal of Research in Marketing, Vol. 34 No. 2, pp.367-381. https://doi.org/10.1016/j.ijresmar.2016.11.002

Du, K., \& Wu, S. J. (2019), "Does external assurance enhance the credibility of CSR reports? Evidence from CSR-related misconduct events in Taiwan." Auditing: A Journal of Practice \& Theory, Vol.38 No.4, pp. 101-130. https://doi.org/10.2308/ajpt-52418

Edgley, C., Jones, M.J., and Atkins, J. (2015), "The adoption of the materiality concept in social and environmental reporting assurance: A field study approach", British Accounting Review, Vol. 47 No. 1, pp. 1-18. https://doi.org/10.1016/j.bar.2014.11.001

Edgley, C., Jones, M.J., and Solomon. J.F. (2010), "Stakeholder inclusivity in social and environmental report assurance", Accounting, Auditing \& Accountability Journal, Vol. 23 No. 4, pp. 532-557. https://doi.org/10.1108/09513571011041615

European Parliament (2012), "Resolution of 8 June 2011 on the external dimension of social policy, promoting labour and social standards and European corporate social responsibility (2010/2205(INI)) (2012/C 380 E/07)”, Official Journal of the European Union. 11.12.2012, 1-12.

European Parliament (2014), "Directive 2014/95/EU of the European Parliament and of the Council of 22 October 2014 amending Directive 2013/34/EU as regards disclosure of nonfinancial and diversity information by certain large undertakings and groups Text with EEA relevance", Official Journal of the European Union. 15.11.2014, 1-9.

Farooq, M.B., and De Villiers, C. (2019a), "How sustainability assurance engagement scopes are determined, and its impact on capture and credibility enhancement", Accounting, Auditing \& Accountability Journal, Vol. 33 No. 2, pp. 417-445. https://doi.org/10.1108/AAAJ-112018-3727 
Farooq, M.B., and De Villiers., C. (2019b), "The shaping of sustainability assurance through the competition between accounting and non-accounting providers", Accounting, Auditing and Accountability Journal, Vol. 32 No. 1, pp. 307-336. https://doi.org/10.1108/AAAJ-102016-2756

Fuhrmann, S., Ott, C., Looks, E., and Guenther, T.W. (2017), "The contents of assurance statements for sustainability reports and information asymmetry", Accounting and Business Research, Vol. 47 No. 4, pp. 369-400. https://doi.org/10.1080/00014788.2016.1263550

Gillet-Monjarret, C., and Rivière-Giordano, G. (2017), "Sustainability assurance: A literature review", Comptabilité-Contrôle-Audit, Vol. 23 No.2, pp.11-62. https://doi.org/10.3917/cca.232.0011

Global Reporting Initiative (GRI) (2013a), "The external assurance of sustainability reporting", Research and Development Series, Global Reporting Initiative, available at: https://www.globalreporting.org/resourcelibrary.

Global Reporting Initiative (GRI) (2013b), "Trends in external assurance of sustainability reports: Spotlight on the USA", Global Reporting Initiative, available at: https://www.globalreporting.org/resourcelibrary.

Gold, N. O., \& Taib, F. M. (2020), "Impact of Corporate Sustainability Reporting Practice on Corporate Performance: a review of literature", International Journal of Industrial Management, Vol. 8, pp. 19-34. https://doi.org/10.15282/ijim.8.0.2020.5760

Herda, D.N., Taylor, M.E., and Winterbotham. G. (2014), "The effect of country-level investor protection on the voluntary assurance of sustainability reports", Journal of International Financial Management and Accounting, Vol. 25 No. 2, pp. 209-236. https://doi.org/10.1111/jifm.12018

Hodge, K., Subramaniam, N., and Stewart, J. (2009), "Assurance of sustainability reports: Impact on report users' confidence and perceptions of information credibility", Australian Accounting Review, Vol. 19 No. 3, pp. 178-194. https://doi.org/10.1111/j.18352561.2009.00056.x

Hudaib, M., and Cooke, T.E. (2005), "The impact of managing director changes and financial 
distress on audit qualification and auditor switching", Journal of Business Finance \& Accounting, Vol. 32 No. (9-10), pp. 1703-1739. https://doi.org/10.1111/j.0306686X.2005.00645.X

International Auditing and Assurance Standards Board (IAASB) (2013), "ISAE 3000 (Revised), Assurance engagements other than audits or reviews of historical financial information", International Auditing and Assurance Standards Board, available at: https://www.iaasb.org/publications-resources/international-standard-assuranceengagements-isae-3000-revised-2.

Institute of Directors Southern Africa (IoDSA) (2009), "King Code of Governance for South Africa”, Institute of Directors Southern Africa, available at: https://cdn.ymaws.com/www.iodsa.co.za/resource/resmgr/king_iii/King_Report_on_Gover nance_fo.pdf.

Isidro, H., Nanda, D. and Wysocki, P.D. (2020), "On the relation between financial reporting quality and country attributes: Research challenges and opportunities", The Accounting Review, Vol. 95 No. 3, pp.279-314. https://doi.org/10.2308/accr-52607

Junior, R.M., Best, P.J., and Cotter, J. (2014), "Sustainability reporting and assurance: A historical analysis on a world-wide phenomenon", Journal of Business Ethics, Vol. 120 No. 1, pp. 1-11. https://doi.org/10.1007/s10551-013-1637-y

Jones, M.J., and Solomon, J.F. (2010), "Social and environmental report assurance: Some interview evidence", Accounting Forum, Vol. 34 No. 1, pp. 20-31. https://doi.org/10.1016/j.accfor.2009.11.002

Kolk, A. (2010), "Trajectories of sustainability reporting by MNCs", Journal of World Business, Vol. 45 No. 4, pp. 367-374. https://doi.org/10.1016/j.jwb.2009.08.001

Kolk, A., and Perego, P. (2010), "Determinants of the adoption of sustainability assurance statements: An international investigation", Business Strategy and the Environment, Vol. 19 No. 3, pp. 182-198. https://doi.org/10.1002/bse.643

KPMG. (2020), "The time has come The KPMG Survey of Sustainability Reporting 2020", KPMG's Global Center of Excellence for Climate Change and Sustainability, available at: 
https://assets.kpmg/content/dam/kpmg/xx/pdf/2020/11/the-time-has-come.pdf

Larrinaga, C., Rossi, A., Luque-Vilchez, M. and Núñez-Nickel, M., (2020), "Institutionalization of the contents of sustainability assurance services: A comparison between Italy and United States", Journal of Business Ethics, Vol. 163 No. 1, pp.67-83. https://doi.org/10.1007/s10551-018-4014-z

Liao, L., Lin, T.P., and Zhang, Y. (2018), "Corporate board and corporate social responsibility assurance: Evidence from China", Journal of Business Ethics, Vol. 150 No. 1, pp. $211-$ 225. https://doi.org/10.1007/s10551-016-3176-9

Lyon, T.P. and Maxwell, J.W. (2011), "Greenwash: Corporate environmental disclosure under threat of audit", Journal of Economics \& Management Strategy, Vol. 20 No. 1, pp.3-41. https://doi.org/10.1111/j.1530-9134.2010.00282.x

Manetti, G., and Becatti, L. (2009), "Assurance services for sustainability reports: Standards and empirical evidence", Journal of Business Ethics, Vol. 87 No. 1, pp. 289-298. https://doi.org/10.1007/s10551-008-9809-x

Manetti, G., and Toccafondi. S. (2012), "The role of stakeholders in sustainability reporting assurance", Journal of Business Ethics, Vol. 107 No. 3, pp. 363-377. https://doi.org/10.1007/s10551-011-1044-1

Maroun, W. (2019), "Exploring the rationale for integrated report assurance", Accounting, Auditing \& Accountability Journal, Vol. 33 No. 8, pp. 18351870. https://doi.org/10.1108/AAAJ-03-2016-2450

Maroun, W. (2018), "A Conceptual Model for Understanding Corporate Social Responsibility Assurance Practice", Journal of Business Ethics, pp. 1-23, available at: https://doi.org/10.1007/s10551-018-3909-z

Michelon, G., Patten, D.M. and Romi, A.M., (2019), "Creating legitimacy for sustainability assurance practices: Evidence from sustainability restatements", European Accounting Review, Vol. 28 No. 2, pp.395-422. https://doi.org/10.1080/09638180.2018.1469424

Mock, T.J., Strohm, C., and Swartz, K.M. (2007), "An examination of worldwide assured sustainability reporting", Australian Accounting Review, Vol. 17 No. 41, pp. 67-77. 
https://doi.org/10.1111/j.1835-2561.2007.tb00455.x

Moroney, R., and Trotman, K.T. (2016), "Differences in auditors' materiality assessments when auditing financial statements and sustainability reports", Contemporary Accounting Research, Vol. 33 No. 2, pp. 551-575. https://doi.org/10.1111/1911-3846.12162

O'Dwyer, B. and Owen, D. (2007), "Seeking stakeholder-centric sustainability assurance: An examination of recent sustainability assurance practice", Journal of Corporate Citizenship, No. 25, pp.77-94. www.jstor.org/stable/jcorpciti.25.77

O’Dwyer, B., Owen, D., and Unerman. J. (2011), "Seeking legitimacy for new assurance forms: The case of assurance on sustainability reporting", Accounting, Organizations and Society, Vol. 36 No. 1, pp. 31-52. https://doi.org/10.1016/j.aos.2011.01.002

Perego, P. (2009), "Causes and consequences of choosing different assurance providers : An international study of sustainability reporting", International Journal of Management, Vol. 26 No. 3, pp. 412-425. http://hdl.handle.net/1765/19537

Perego, P., and Kolk, A. (2012), "Multinationals' accountability on sustainability: The evolution of third-party assurance of sustainability reports", Journal of Business Ethics, Vol. 110 No. 2, pp. 173-190. https://doi.org/10.1007/s10551-012-1420-5

Peters, G.F., and Romi. A.M. (2015), "The association between sustainability governance characteristics and the assurance of corporate sustainability reports", Auditing: A Journal of Practice \& Theory, Vol. 34 No. 1, pp. 163-198. https://doi.org/10.2308/ajpt-50849

Pflugrath, G., Roebuck, P., and Simnett. R. (2011), "Impact of assurance and assurer's professional affiliation on financial analysts' assessment of credibility of corporate social responsibility information", Auditing: A Journal of Practice \& Theory, Vol. 30 No. 3, pp. 239-254. https://doi.org/10.2308/ajpt-10047

Proposal for a directive of the european parliament and of the council amending Directive 2013/34/EU, Directive 2004/109/EC, Directive 2006/43/EC and Regulation (EU) No $537 / 2014$, as regards corporate sustainability reporting.

Reimsbach, D., Hahn, R., and Gürtürk. A. (2017), "Integrated reporting and assurance of sustainability information: An experimental study on professional investors' information 
processing", European Accounting Review, Vol. 26 No. 1, pp. 1-23.

https://doi.org/10.1080/09638180.2016.1273787

Rivière-Giordano, G., Giordano-Spring, S. and Cho, C.H. (2018). "Does the level of assurance statement on environmental disclosure affect investor assessment? An experimental study", Sustainability Accounting, Management and Policy Journal, Vol. 9 No. 3, pp.3363360. https://doi.org/10.1108/SAMPJ-03-2018-0054

Sherif, M., Taub, D. and Hovland, C.I. (1958), “Assimilation and contrast effects of anchoring stimuli on judgments", Journal of experimental psychology, Vol. 55 No. 2, pp150-155. https://psycnet.apa.org/doi/10.1037/h0048784

Simnett, R., Vanstraelen, A., and Chua, W.F. (2009), "Assurance on sustainability reports: An international comparison", The Accounting Review, Vol. 84 No. 3, pp. 937-967. https://doi.org/10.2308/accr.2009.84.3.937

United Nations Conference on Sustainable Development - Rio+20. (2012), "Sustainable Development", available at: https://sustainabledevelopment.un.org/rio20.

Walker, K., and Wan, F. (2012), "The harm of symbolic actions and green-washing: Corporate actions and communications on environmental performance and their financial implications", Journal of Business Ethics, Vol. 109 No. 2, pp. 227-242. https://doi.org/10.1007/s10551-011-1122-4

Wong, R., \& Millington, A. (2014), "Corporate social disclosures: a user perspective on assurance", Accounting, Auditing \& Accountability Journal, Vol. 27 No. 5, 863-887. https://doi.org/10.1108/AAAJ-06-2013-1389

World Business Council for Sustainable Development (2016), "Generating Value from External Assurance of Sustainability Reporting”, World Business Council for Sustainable Development, available at: http://wbcsdpublications.org/wpcontent/uploads/2016/03/WBCSD_Redefining_assurance_guide.pdf. 
Table 1. Sustainability reports and assurance growth

\begin{tabular}{lcccc}
\hline & $\begin{array}{c}\text { Sustainability } \\
\text { reports }\end{array}$ & Not assured & Assured & $\begin{array}{c}\text { Percentage } \\
\text { assured (\%) }\end{array}$ \\
\cline { 2 - 5 } 2012 & 4,637 & 3,422 & 1,212 & 26.1 \\
2013 & 5,229 & 3,858 & 1,370 & 26.2 \\
2014 & 5,812 & 4,315 & 1,496 & 25.7 \\
2015 & 6,195 & 4,664 & 1,530 & 24.7 \\
2016 & 6,870 & 5,280 & 1,587 & 23.1 \\
2017 & 7,244 & 5,788 & 1,456 & 20.1 \\
\hline Percentage of increase (\%) & $\mathbf{5 6 . 2}$ & $\mathbf{6 9 . 1}$ & $\mathbf{2 0 . 1}$ & $\mathbf{- 2 3}$ \\
\hline
\end{tabular}




\begin{tabular}{|c|c|c|c|c|c|c|}
\hline \multirow[b]{2}{*}{ Region } & \multicolumn{2}{|c|}{$\begin{array}{l}\text { Sustainability } \\
\text { reports }\end{array}$} & \multicolumn{2}{|c|}{$\begin{array}{c}\text { Assured } \\
\text { sustainability } \\
\text { reports }\end{array}$} & \multirow{2}{*}{$\begin{array}{c}\Delta \text { Sustainability } \\
\text { reports }\end{array}$} & \multirow{2}{*}{$\begin{array}{c}\begin{array}{c}\Delta \text { Assured } \\
\text { sustainability } \\
\text { reports }\end{array} \\
\mathbf{2 0 1 2 - 2 0 1 7} \\
\end{array}$} \\
\hline & 2012 & 2017 & 2012 & 2017 & & \\
\hline Africa & 330 & 442 & 57 & 47 & $112 * *$ & -10 \\
\hline Asia & 1,242 & 2,930 & 278 & 567 & $1,688 * * *$ & $289 * * *$ \\
\hline Europe & 1,732 & 2,173 & 570 & 532 & $441 * *$ & -38 \\
\hline $\begin{array}{l}\text { Latin America and } \\
\text { the Caribbean }\end{array}$ & 567 & 889 & 157 & 182 & $322 * * *$ & 25 \\
\hline Northern America & 588 & 641 & 85 & 95 & 53 & 10 \\
\hline Oceania & 175 & 168 & 65 & 33 & -7 & -32 \\
\hline Total & 4,634 & 7,243 & 1,212 & 1,456 & $2,609 * * *$ & $244 * *$ \\
\hline
\end{tabular}




\begin{tabular}{|c|c|c|c|c|c|c|}
\hline \multirow[b]{2}{*}{ Industry } & \multicolumn{2}{|c|}{$\begin{array}{l}\text { Sustainability } \\
\text { reports }\end{array}$} & \multicolumn{2}{|c|}{$\begin{array}{c}\text { Assured } \\
\text { sustainability } \\
\text { reports }\end{array}$} & \multirow{2}{*}{$\begin{array}{c}\Delta \text { Sustainability } \\
\text { reports }\end{array}$} & \multirow{2}{*}{$\begin{array}{c}\begin{array}{c}\Delta \text { Assured } \\
\text { sustainability } \\
\text { reports }\end{array} \\
2012-2017 \\
\end{array}$} \\
\hline & 2012 & 2017 & 2012 & 2017 & & \\
\hline Chemicals & 164 & 268 & 41 & 67 & $104 * *$ & 26 \\
\hline Construction & 159 & 206 & 42 & 40 & 47 & -2 \\
\hline Energy & 292 & 439 & 105 & 103 & $147 * *$ & -2 \\
\hline Energy Utilities & 200 & 209 & 72 & 58 & 9 & -14 \\
\hline Financial Services & 539 & 1034 & 178 & 229 & $495 * * *$ & 51 \\
\hline Food and Beverage & 286 & 426 & 61 & 82 & $140 * *$ & 21 \\
\hline Mining & 192 & 216 & 56 & 58 & 24 & 2 \\
\hline Real Estate & 153 & 284 & 28 & 52 & $131 * * *$ & 24 \\
\hline Retailers & 129 & 191 & 14 & 33 & 62 & 19 \\
\hline Telecommunications & 150 & 199 & 56 & 62 & 49 & 6 \\
\hline Other & 2,291 & 3,772 & 559 & 672 & $1481 * * *$ & 113 \\
\hline Total & 4,555 & 7,244 & 1,212 & 1,456 & $2,689 * * *$ & $244 * *$ \\
\hline
\end{tabular}


Table 4. Assured sustainability reports by company type, listed status and size

\begin{tabular}{|c|c|c|c|c|c|c|}
\hline \multirow[b]{2}{*}{ Company type } & \multicolumn{2}{|c|}{$\begin{array}{l}\text { Sustainability } \\
\text { reports }\end{array}$} & \multicolumn{2}{|c|}{$\begin{array}{c}\text { Assured } \\
\text { sustainability } \\
\text { reports } \\
\end{array}$} & \multirow{2}{*}{$\begin{array}{c}\Delta \text { Sustainability } \\
\text { reports }\end{array}$} & \multirow{2}{*}{$\begin{array}{c}\begin{array}{c}\Delta \text { Assured } \\
\text { sustainability } \\
\text { reports }\end{array} \\
\text { 2012-2017 } \\
\end{array}$} \\
\hline & 2012 & 2017 & 2012 & 2017 & & \\
\hline Cooperative & 45 & 93 & 12 & 15 & 48 & 3 \\
\hline $\begin{array}{l}\text { Non-profit } \\
\text { organization }\end{array}$ & 133 & 173 & 21 & 26 & 40 & 5 \\
\hline Partnership & 37 & 33 & 6 & 6 & -4 & 0 \\
\hline Private company & 3,367 & 5,435 & 903 & 1,179 & $2,068 * * *$ & $276^{* *}$ \\
\hline Public institution & 155 & 189 & 38 & 24 & 34 & -14 \\
\hline State-owned company & 505 & 844 & 148 & 135 & $339 * * *$ & -13 \\
\hline Subsidiary & 392 & 474 & 84 & 69 & 82 & -15 \\
\hline Total & 4,634 & 7,241 & 1,212 & 1,454 & $2,607 * * *$ & $242 * *$ \\
\hline \multicolumn{7}{|l|}{ Listed status } \\
\hline Listed & 2,744 & 5,032 & 761 & 1,084 & $2,288 * * *$ & $323 * * *$ \\
\hline Non-listed & 1,845 & 2,168 & 446 & 368 & $323 * * *$ & -78 \\
\hline Total & 4,589 & 7,200 & 1,207 & 1,452 & $2,611 * * *$ & $245 * *$ \\
\hline \multicolumn{7}{|l|}{ Size $^{\dagger}$} \\
\hline Large & 2,819 & 4,404 & 884 & 869 & $1,585 * * *$ & -15 \\
\hline MNE & 1,183 & 2,012 & 275 & 511 & $829 * * *$ & $236 * * *$ \\
\hline SME & 465 & 828 & 93 & 76 & $363 * * *$ & -17 \\
\hline Total & 4,467 & 7,244 & 1,252 & 1,456 & $2,777 * * *$ & $204 * *$ \\
\hline
\end{tabular}




\begin{tabular}{lccc}
\hline \multicolumn{2}{l}{ Table 5. Time difference between first sustainability reports and first assured sustainability reports } \\
\hline Variable & Observations & Mean & Standard Deviation \\
\hline Time difference & 3,302 & 2.05 & 2.76 \\
\hline Region & Observations & Mean & Standard Deviation \\
\hline Africa & 128 & 3.25 & 3.10 \\
Asia & 1,048 & 1.69 & 2.74 \\
Europe & 1,340 & 1.99 & 2.62 \\
Latin America and the Caribbean & 427 & 1.77 & 2.33 \\
Northern America & 233 & 3.64 & 3.45 \\
Oceania & 126 & 2.45 & 2.70 \\
\hline Total & $\mathbf{3 , 3 0 2}$ & $\mathbf{2 . 0 5}$ & $\mathbf{2 . 7 6}$ \\
\hline Company Size & Observations & Mean & Standard Deviation \\
\hline Large & 2,083 & 2.08 & 2.74 \\
MNE & 908 & 2.35 & 3.00 \\
SME & 311 & 0.97 & 1.81 \\
\hline Total & $\mathbf{3 , 3 0 2}$ & $\mathbf{2 . 0 5}$ & $\mathbf{2 . 7 6}$ \\
\hline
\end{tabular}




\begin{tabular}{|c|c|c|c|}
\hline \multicolumn{4}{|c|}{ Table 6. Sustainability report assurance by type of assurer } \\
\hline Assurance provider & 2012 & 2017 & $\Delta$ 2012-2017 \\
\hline Accounting & 717 & 899 & $182^{*}$ \\
\hline Engineering & 196 & 320 & $124 * *$ \\
\hline Consulting & 289 & 224 & -65 \\
\hline Total & 1,202 & 1,443 & $241 * *$ \\
\hline
\end{tabular}




\begin{tabular}{|c|c|c|c|c|c|c|c|c|c|}
\hline \multirow[b]{2}{*}{ Region } & \multicolumn{2}{|c|}{ Accounting } & \multicolumn{2}{|c|}{ Engineering } & \multicolumn{2}{|c|}{ Consulting } & \multirow{2}{*}{$\begin{array}{c}\Delta \\
\text { Accounting } \\
2012-2017\end{array}$} & \multirow{2}{*}{$\begin{array}{c}\Delta \\
\text { Engineering } \\
\text { 2012-2017 }\end{array}$} & \multirow{2}{*}{$\begin{array}{c}\Delta \text { Consulting } \\
2012-2017\end{array}$} \\
\hline & 2012 & 2017 & 2012 & 2017 & 2012 & 2017 & & & \\
\hline Africa & 36 & 37 & 4 & 0 & 17 & 9 & 1 & -4 & -8 \\
\hline Asia & 93 & 238 & 79 & 230 & 103 & 94 & $145^{* * *}$ & $151 * * *$ & -9 \\
\hline Europe & 406 & 424 & 75 & 45 & 80 & 59 & 18 & -30 & -21 \\
\hline $\begin{array}{l}\text { Latin America and } \\
\text { the Caribbean }\end{array}$ & 111 & 130 & 11 & 9 & 33 & 40 & 19 & -2 & 7 \\
\hline Northern America & 39 & 41 & 19 & 32 & 27 & 22 & 2 & 13 & -5 \\
\hline Oceania & 30 & 29 & 6 & 4 & 28 & 0 & -1 & -2 & -28 \\
\hline Total & 715 & 899 & 194 & 320 & 288 & 224 & 184* & $126 * *$ & -64 \\
\hline Company type & & 3 & & & & & & & \\
\hline Cooperative & 9 & 10 & 1 & 2 & 2 & 3 & 1 & 1 & 1 \\
\hline $\begin{array}{l}\text { Non-profit } \\
\text { organization }\end{array}$ & 14 & 13 & 2 & 4 & 6 & 9 & -1 & 2 & 3 \\
\hline Partnership & 2 & 4 & 1 & 0 & 3 & 2 & 2 & -1 & -1 \\
\hline Private company & 524 & 711 & 143 & 283 & 231 & 174 & $187 * *$ & $140 * *$ & -57 \\
\hline Public institution & 15 & 13 & 13 & 6 & 10 & 5 & -2 & -7 & -5 \\
\hline $\begin{array}{l}\text { State-owned } \\
\text { company }\end{array}$ & 105 & 101 & 19 & 18 & 20 & 15 & -4 & -1 & -5 \\
\hline Subsidiary & 48 & 46 & 17 & 6 & 17 & 16 & -2 & -11 & -1 \\
\hline Total & 717 & 898 & 196 & 319 & 289 & 224 & 181* & $123 * *$ & -65 \\
\hline Industry & & & & & & 8 & & & \\
\hline Chemicals & 22 & 36 & 9 & 19 & 10 & 11 & 14 & 10 & 1 \\
\hline Construction & 20 & 23 & 12 & 7 & 10 & 9 & 3 & -5 & -1 \\
\hline Energy & 69 & 77 & 17 & 11 & 14 & 15 & 8 & -6 & 1 \\
\hline Energy Utilities & 51 & 44 & 9 & 6 & 12 & 8 & -7 & -3 & -4 \\
\hline Financial Services & 127 & 153 & 12 & 37 & 36 & 38 & 26 & 25 & 2 \\
\hline Food and Beverage & 33 & 67 & 5 & 10 & 23 & 5 & 34 & 5 & -18 \\
\hline Mining & 37 & 39 & 9 & 10 & 9 & 9 & 2 & 1 & 0 \\
\hline Real Estate & 16 & 36 & 5 & 6 & 7 & 10 & 20 & 1 & 3 \\
\hline Retailers & 7 & 26 & 3 & 5 & 4 & 2 & 19 & 2 & -2 \\
\hline Telecommunications & 37 & 40 & 8 & 15 & 11 & 7 & 3 & 7 & -4 \\
\hline Other & 296 & 358 & 105 & 194 & 152 & 110 & 62 & 89 & -42 \\
\hline Total & 715 & 899 & 194 & 320 & 288 & 224 & $184 *$ & $126 *$ & -64 \\
\hline
\end{tabular}


Table 8. The use of assurance standards, scope and level of assurance

Panel A: The use of assurance standards

\begin{tabular}{lccc}
\hline Assurance Standards & $\mathbf{2 0 1 2}$ & $\mathbf{2 0 1 7}$ & $\Delta \mathbf{2 0 1 2 - 2 0 1 7}$ \\
\hline AA1000 & 245 & 405 & $160^{* *}$ \\
ISAE 3000 & 290 & 735 & $445^{* * *}$ \\
AA1000 and ISAE $3000 \ddagger$ & 98 & 115 & 17 \\
\hline Total & $\mathbf{6 3 3}$ & $\mathbf{1 , 2 5 5}$ & $\mathbf{6 2 2 * * *}$ \\
\hline
\end{tabular}

Panel B: The use of assurance standards by type of assurer

\begin{tabular}{lccc}
\hline & $\Delta$ AA1000 & $\Delta$ ISAE 3000 & $\Delta$ AA1000 and \\
Assurance Standards & $\mathbf{2 0 1 2 - 2 0 1 7}$ & $\mathbf{2 0 1 2 - 2 0 1 7}$ & $\mathbf{2 0 1 2 - 2 0 1 7}$ \\
& & & 8 \\
\hline Accounting & -11 & $268^{* * *}$ & -5 \\
Engineering & $99 * *$ & $46^{*}$ & 14 \\
Consulting & -23 & 24 & $\mathbf{1 7}$ \\
\hline Total & $\mathbf{6 5}$ & $\mathbf{3 3 8 * *}$ & \\
\hline
\end{tabular}

Panel C: Assurance scope and level of assurance by type of assurance provider $(\%)^{\dagger}$

\begin{tabular}{lll}
\hline Assurance provider Assurance scope & Level of assurance
\end{tabular}

\begin{tabular}{lcccc}
\hline & entire report & sections & limited/moderate & reasonable / high \\
\cline { 2 - 5 } Accounting & 39 & 51 & 78 & 8 \\
Engineering & 61 & 27 & 65 & 16 \\
Consulting & 54 & 29 & 57 & 12 \\
\hline
\end{tabular}

Chi-square tests, ${ }^{*} \mathrm{p}<0.10,{ }^{* *} \mathrm{p}<0.05,{ }^{* * *} \mathrm{p}<0.01$

$\dagger$ The percentage is calculated based on the total assurance report provided by each type.

$\$$ Combined both AA1000 and ISAE 3000 
Table 9. Assurer switch

\begin{tabular}{lcccccc}
\hline & $\begin{array}{c}\text { Switch 12/13 } \\
\text { Number of } \\
\text { switches (\%) }\end{array}$ & $\begin{array}{c}\text { Switch 13/14 } \\
\text { Number of } \\
\text { switches (\%) }\end{array}$ & $\begin{array}{c}\text { Switch 14/15 } \\
\text { Number of } \\
\text { switches (\%) }\end{array}$ & $\begin{array}{c}\text { Switch 15/16 } \\
\text { Number of } \\
\text { switches (\%) }\end{array}$ & $\begin{array}{c}\text { Switch 16/17 } \\
\text { Number of } \\
\text { switches (\%) }\end{array}$ & $\begin{array}{c}\Delta \text { Switch 12/13 - } \\
\text { Switch 16/17 }\end{array}$ \\
\hline To no-assurance & $49(19)$ & $81(30)$ & $124(39)$ & $135(39)$ & $137(41)$ & $88 * * *$ \\
To accounting & $28(11)$ & $24(9)$ & $31(10)$ & $30(9)$ & $21(6)$ & -7 \\
To engineering & $23(9)$ & $32(12)$ & $26(8)$ & $19(6)$ & $31(9)$ & 8 \\
To consulting & $26(10)$ & $29(11)$ & $32(10)$ & $35(10)$ & $31(9)$ & 5 \\
From no-assurance to assurance & $134(52)$ & $100(38)$ & $107(33)$ & $126(37)$ & $114(34)$ & -20 \\
\hline Chi-square tests, ${ }^{*} p<0.10,{ }^{* *} p<0.05,{ }^{* * *} \mathrm{p}<0.01$ & & & & &
\end{tabular}




\section{Table 10. Future research in sustainability assurance}

\begin{tabular}{|c|c|c|c|c|}
\hline $\begin{array}{l}\text { Research questions in this } \\
\text { study }\end{array}$ & Our findings & Future research questions & Level of analysis & $\begin{array}{l}\text { Main theories that could } \\
\text { guide the research }\end{array}$ \\
\hline \multirow{3}{*}{$\begin{array}{l}\text { Analyse institutional and firm- } \\
\text { level characteristics in terms of } \\
\text { assurance adoption }\end{array}$} & $\begin{array}{l}\text { Significant variation in the } \\
\text { growth of sustainability report } \\
\text { assurance among different }\end{array}$ & $\begin{array}{l}\text { What is the perceived value of assurance } \\
\text { across different regions, industries, } \\
\text { company types, listed status and size? }\end{array}$ & $\begin{array}{l}\text { Individual-level } \\
\text { (or intended users) }\end{array}$ & Assimilation-contrast theory \\
\hline & & $\begin{array}{l}\text { What institutional factors could explain } \\
\text { variations in the assurance of } \\
\text { sustainability reports (e.g., institutional } \\
\text { investors or country factors)? }\end{array}$ & Market level & $\begin{array}{l}\text { Agency theory } \\
\text { Institutional theory }\end{array}$ \\
\hline & $\begin{array}{l}\text { The time companies take to } \\
\text { assure their sustainability } \\
\text { reports after they are first } \\
\text { issued vary based on region } \\
\text { and company size. }\end{array}$ & $\begin{array}{l}\text { When is it the right time to assure a } \\
\text { sustainability report? } \\
\text { How this decision affects companies and } \\
\text { stakeholders? }\end{array}$ & $\begin{array}{l}\text { Individual and } \\
\text { market-level } \\
\text { (intended users) }\end{array}$ & Legitimacy theory \\
\hline \multirow{3}{*}{$\begin{array}{l}\text { Analyse market distribution } \\
\text { among different assurance } \\
\text { provider and their practice in } \\
\text { terms of scope, level of } \\
\text { assurance and standards used }\end{array}$} & $\begin{array}{l}\text { The number of sustainability } \\
\text { reports assured by engineering } \\
\text { firms has significantly grown } \\
\text { in recent years in comparison } \\
\text { with the two other assurer } \\
\text { types, while assurance by } \\
\text { consulting firms presented a } \\
\text { decrease. }\end{array}$ & $\begin{array}{l}\text { What factors drive companies to choose a } \\
\text { particular assurance provider? } \\
\text { How availability, service quality, } \\
\text { reputation and/or price affect the choice } \\
\text { of the type of assurer? }\end{array}$ & Organization level & $\begin{array}{l}\text { Stakeholder theory } \\
\text { Agency theory } \\
\text { Institutional theory } \\
\text { Contingency Theory }\end{array}$ \\
\hline & $\begin{array}{l}\text { An increase in the use of the } \\
\text { ISAE } 3000 \text { by non-accounting } \\
\text { assurance providers. }\end{array}$ & $\begin{array}{c}\text { Why is there an increase in the use of } \\
\text { ISAE } 3000 \text { by non-accounting assurance } \\
\text { providers? }\end{array}$ & Market level & Legitimacy theory \\
\hline & & $\begin{array}{l}\text { Does the use of ISAE } 3000 \text { standard by } \\
\text { non-accounting assurance providers } \\
\text { increase the quality of their assurance, } \\
\text { their reliability and comparability? Does }\end{array}$ & & \\
\hline
\end{tabular}




\begin{tabular}{|c|c|c|c|c|}
\hline & & $\begin{array}{l}\text { it increase legitimacy over the assurance } \\
\text { provided? }\end{array}$ & & \\
\hline \multirow[t]{2}{*}{$\begin{array}{l}\text { Document companies } \\
\text { consistency in terms of } \\
\text { assurance adoption and their } \\
\text { choice of assurance provider. }\end{array}$} & $\begin{array}{l}\text { Only a minority of consistent } \\
\text { reporters are consistent } \\
\text { assurers. The majority of } \\
\text { companies that provide } \\
\text { sustainability reports } \\
\text { consistently do not provide any } \\
\text { assurance over the tested } \\
\text { period. }\end{array}$ & $\begin{array}{l}\text { Why companies that consistently issue } \\
\text { sustainability reports do not provide } \\
\text { assurance? Are they using different } \\
\text { credibility-enhancing mechanisms (e.g., } \\
\text { internal audit or stakeholder panel)? Do } \\
\text { such mechanisms act as a substitute for } \\
\text { independent external assurance or } \\
\text { complementary? }\end{array}$ & Organization level & Signalling Theory \\
\hline & $\begin{array}{l}\text { Switching is a common } \\
\text { practice }\end{array}$ & $\begin{array}{l}\text { Examine the mixed signals to } \\
\text { stakeholders and the risk of } \\
\text { discontinuation effect. }\end{array}$ & $\begin{array}{l}\text { Organization and } \\
\text { stakeholder level }\end{array}$ & Signalling theory \\
\hline
\end{tabular}


Figure 1: Assurance providers' classification

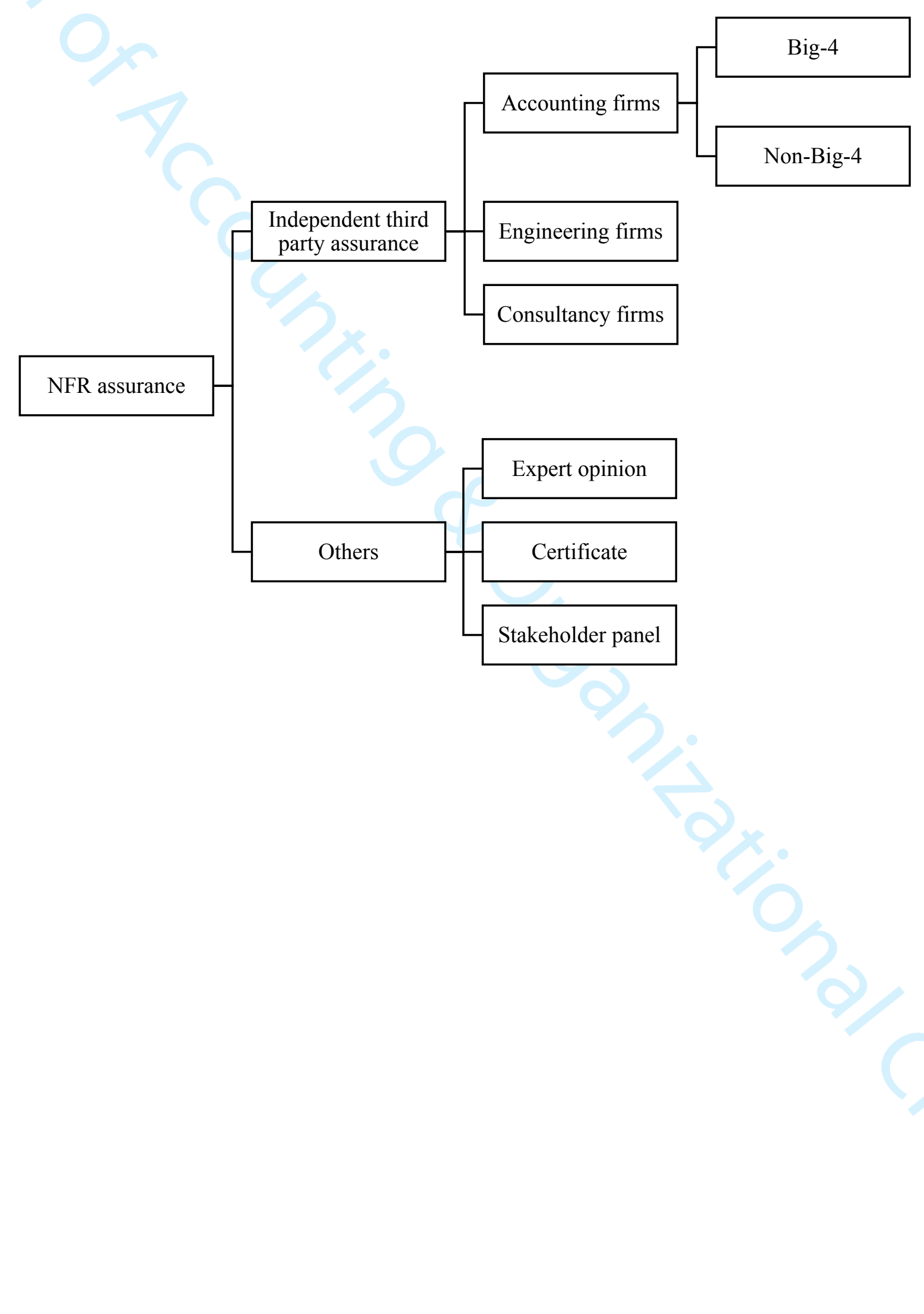


Figure 2: Tree map for companies' classification based on issuing sustainability reports and assurance

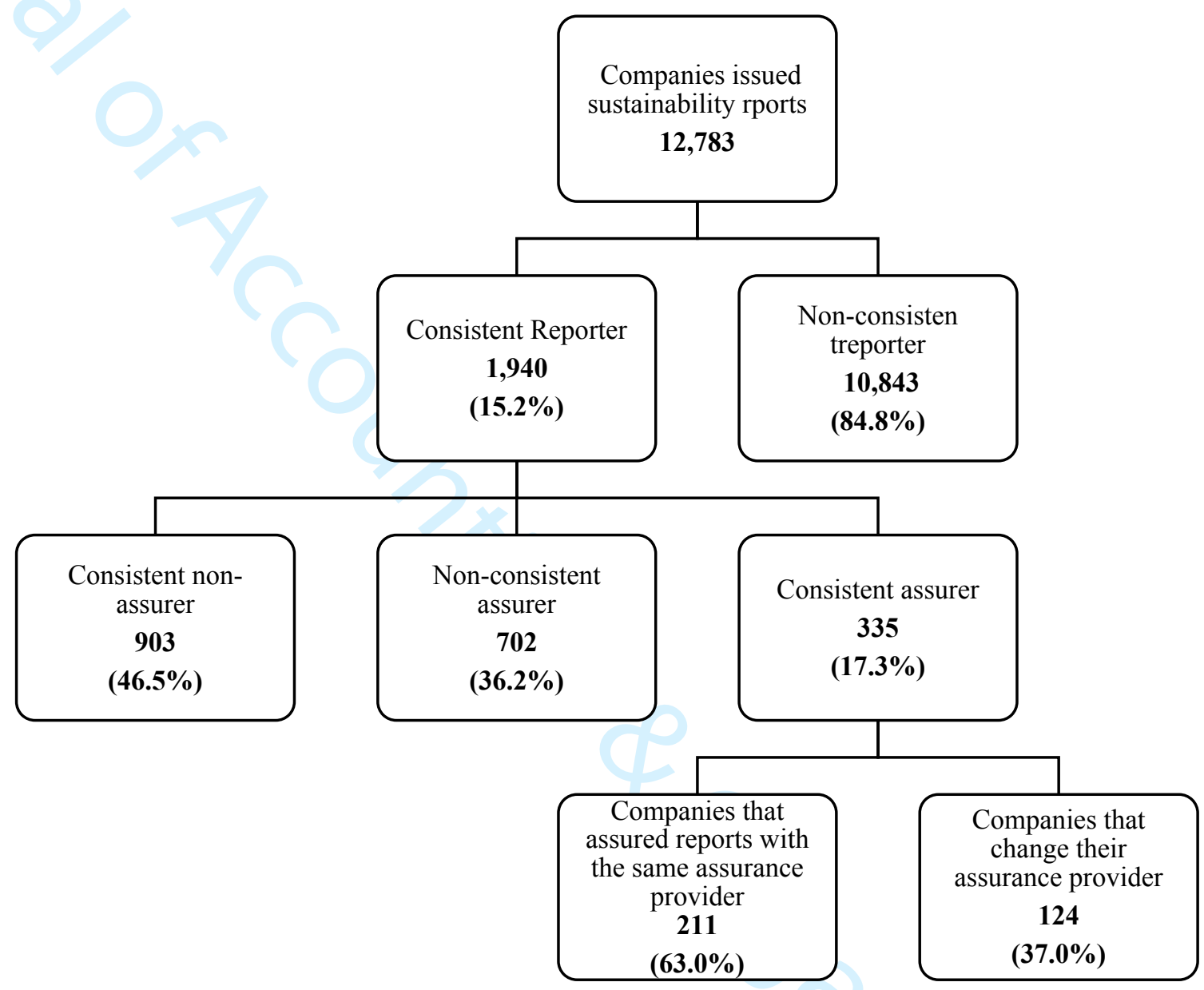

